\title{
Epidemiology and Management of Bacterial Spot of Almond Caused by Xanthomonas arboricola pv. pruni, a New Disease in California
}

\author{
Stacey E. Haack, ${ }^{1}$ Layne Wade, ${ }^{2}$ Helga Förster, ${ }^{1}$ and James E. Adaskaveg ${ }^{1, \dagger}$ \\ ${ }^{1}$ Department of Microbiology and Plant Pathology, University of California, Riverside, CA 92521 \\ ${ }^{2}$ Grow West, Woodland, CA 95776
}

\begin{abstract}
Bacterial spot caused by Xanthomonas arboricola pv. pruni was first detected on almond in California in 2013, and it is reported herein as a new disease in California based on fulfilling Koch's postulates and identification of the pathogen using species-specific PCR primers. Infected mummified fruit from the previous growing season and their peduncles were identified as primary overwintering sites of the bacterium on the tree. Twig cankers were not observed, and the pathogen was not recovered from dormant buds. Isolation from flowers and emerging leaves was only successful when they were collected within $20 \mathrm{~cm}$ of an infected, mummified fruit on the tree. Inoculation of flowers and immature fruit as well

applications in December or January with copper or copper-mancozeb significantly reduced the disease compared with untreated controls in seasons with high rainfall, but they had no effect in seasons with low rainfall. In-season applications of copper-mancozeb at petal fall or at full bloom and petal fall were also effective in reducing the disease. Phytotoxicity was observed after repeated applications of copper bactericides, especially in low-rainfall seasons. Dormant and in-season treatments of copper-mancozeb mixtures integrated with removal of mummified fruit are currently the best management strategies for bacterial spot of almond in California.
\end{abstract} as immature and mature leaves resulted in disease development, indicating a long period of host susceptibility in the spring, but disease incidence was highest in fruit inoculations. In split-plot trials over 3 years, dormant

Keywords: bacterial disease, dormant treatments, in-season treatments, nut tree disease, overwintering mechanism

Bacterial spot of almond (Prunus dulcis [Mill.] D. A. Webb) and other Prunus species has been reported in most regions of the world where these crops are grown (EPPO 2015; Ritchie 1995). The pathogen Xanthomonas arboricola pv. pruni (syn. Xanthomonas campestris pv. pruni Smith) (Smith 1903; Vauterin et al. 1995) was first reported in Michigan on Japanese plum in 1903 (Smith 1903). Among commercially grown Prunus species, bacterial spot has had the highest economic impact on Japanese plum, peach, and nectarine, but it can also affect European plum (Stefani 2010). Although $X$. arboricola pv. pruni is listed as a quarantine organism (list A2; locally present but with limited distribution) by the European and Mediterranean Plant Protection Organization (EPPO 1997), it is not identified as such by other regional quarantine regulatory agencies (Lamichhane 2014).

The disease was reported on almond in New Zealand in the 1970s (Young 1977); in Australia, India, and Pakistan in the 1990s (Akhatar et al. 1995; EPPO 1997; Jindal et al. 1990); and in Spain in 2010 (Palacio-Bielsa et al. 2010). In Australia, exacerbated by common spring rains, the disease is of major concern, especially on the susceptible cultivars Fritz and NePlus Ultra. These cultivars are now rarely planted, and many existing orchards have been removed because of excessive crop losses (Palacio-Bielsa et al. 2017).

Fruit symptoms on almond are somewhat distinct from those observed on other Prunus hosts (Roselló et al. 2012). Infections start as small, watery, sunken blemishes on the hull (i.e., mesocarp) that darken, enlarge, and exude light to dark amber-colored gum. Gumming may accumulate as a distinct drop or may continue to form a long tendril on the hull surface. Upon removal of the hull epidermis

${ }^{\dagger}$ Corresponding author: J. E. Adaskaveg; jim.adaskaveg@ucr.edu

Funding: This research was financially supported by the Almond Board of California.

The author(s) declare no conflict of interest.

Accepted for publication 23 January 2020.

(C) 2020 The American Phytopathological Society at the gumming sites, diagnostic brown corky lesions can be observed extending into the fruit. Infections sometimes reach the shell and kernel, causing darkening of the endosperm and therefore, downgrading the quality of the crop. Multiple infections can occur on a single fruit, and infected fruit may drop prematurely or remain on the tree (i.e., "stick tights") following harvest. Infected fruit on the tree develop into mummified fruit ("mummies") that may remain on the tree throughout dormancy and into the next growing season. Leaf spots are concentrated in areas of the leaf that remain wet for longer periods of time, including the tip, the margins, and along the midrib. Lesions begin as angular, water-soaked areas surrounded by chlorotic tissue that later may coalesce, become necrotic, and may abscise, creating "shot holes" in the leaves. Leaf symptoms can appear similar to copper phytotoxicity or shot hole caused by the fungal pathogen Wilsonomyces carpophilus.

Disease symptoms were first observed in California during the spring 2013 season at high incidence on fruit in some orchard locations in Colusa, San Joaquin, Stanislaus, Merced, and Madera counties (Holtz et al. 2013). The disease was especially prevalent on the cultivar Fritz, but it was also observed on the cultivars Nonpareil, Butte, Carmel, and Price. Following consistent isolation of X. arboricola pv pruni as identified by morphological (EPPO 2005) and molecular (Pagani 2004) techniques, the disease was diagnosed as bacterial spot of almond (Holtz et al. 2013), and Koch's postulates are reported herein. Because fruit symptoms appear similar to leaffooted bug (Leptoglossus spp.) damage or anthracnose (Colletotrichum acutatum species complex), it is possible that bacterial spot was present for some time in these regions in California but that it was misdiagnosed. Since then, the disease has additionally been observed on cultivars Aldrich, NePlus Ultra, Winters, and Wood Colony, and it was confirmed in additional counties in California (e.g., Butte and Kern) (J. E. Adaskaveg, unpublished data).

On almond, copper and copper-based mixtures are reported to have marginal efficacy against the disease (Palacio-Bielsa et al. 2017), but there have not been any comprehensive studies evaluating application efficacy or timing. On peach in the eastern United States, three to five applications of copper products or the antibiotic oxytetracycline are done prior to shuck split. This program is efficacious under low to moderate disease pressure based on environmental conditions (Ritchie 1999; Ritchie et al. 2008). Later application of 
copper-based compounds increases the risk of copper phytotoxicity on Prunus spp., with increased risk following repeated applications (Blaauw et al. 2019; Ritchie et al. 2008). Copper ions function in many ways to cause bacterial cell death, including disruption of the integrity of cell membranes, induction of reactive oxygen species, DNA damage, and respiratory inhibition (Fones and Preston 2013; FRAC 2019; Grass et al. 2011), and they are contact-dependent for efficacy.

In the United States, the coordination fungicide of zinc and manganese ethylene bis-dithiocarbamate (mancozeb) is also used either alone or in mixtures with copper or other bactericides for the management of bacterial diseases, including those caused by Xanthomonas spp. (Buchner et al. 2010; Gullino et al. 2010). It is also classified as having a multisite mode of action, with active breakdown products thought to interfere with enzymes in the cell cytoplasm and mitochondria (FRAC 2019; Gullino et al. 2010). Copper and mancozeb products are currently registered on almond in California for managing selected fungal and bacterial diseases. Both are approved for use against brown rot blossom blight and shot hole, whereas copper is also used against bacterial blast, and mancozeb is also registered against rust and scab. Labels potentially can be amended to include management of bacterial spot caused by $X$. arboricola pv. pruni. Mancozeb has not been associated with phytotoxicity on almond.

Although much is known about the epidemiology and management of bacterial spot on other Prunus hosts worldwide, information on the disease on almond in California is limited. Therefore, studies were conducted over several growing seasons to better understand the epidemiology of bacterial spot in California almond orchards and to investigate management options. Specific objectives were to (i) demonstrate Koch's postulates and provide definitive identification of the pathogen using molecular methods; (ii) identify overwintering sites of the bacterium on almond trees; (iii) determine timing of infection to compare susceptibility of flowers, fruit, and leaves; and (iv) determine if dormant bactericide applications targeting overwintering populations of the pathogen reduce disease in the following spring season and determine relative efficacy of in-season bactericide applications for the most efficacious disease management strategy.

\section{Materials and Methods}

Collection of potential overwintering inoculum sources of $X$. arboricola pv. pruni and bacterial isolation and identification. Collections were made between 2014 and 2018 from two 15- to 20-year-old commercial almond orchards in San Joaquin Country, California, planted 1:1 with single rows of Fritz and Nonpareil

Table 1. Recovery of Xanthomonas arboricola pv. pruni from almond tissues collected in the field

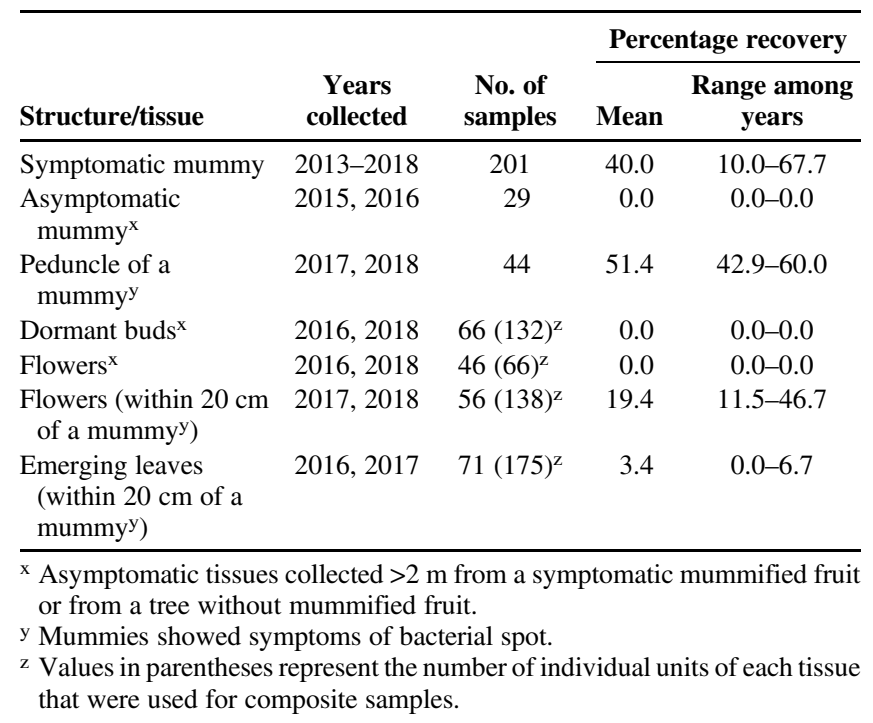

cultivars. Symptomatic tissues collected included mummified fruit (dehydrated fruit from the previous season) with raised lesions and amber-colored gumming and peduncles (that persist on the almond spur after fruits are removed) associated with these mummies also with amber-colored gumming that was visible after the mummies were removed. Mummies were collected from the tree or from the orchard floor if sufficient numbers could not be found in the tree. Asymptomatic tissues collected included dormant buds, flowers, emerging leaves, and fruit mummies without raised lesions or gumming. Flowers and emerging leaves were collected within $20 \mathrm{~cm}$ or $>2 \mathrm{~m}$ from a symptomatic mummified fruit or from a tree without mummified fruit (Table 1). Dormant buds were collected from trees without symptomatic mummies. Sampling of tissues was done between December and July. Mummies and associated peduncles were surface disinfested in $1 \%$ sodium hypochlorite for $1 \mathrm{~min}$ and triple rinsed with sterile distilled water. Mummies were soaked in sterile deionized water for 15 to $30 \mathrm{~min}$ to soften tissues. The outer hull layer was removed using a sterile razor blade, and tissues of raised brown corky lesions of symptomatic mummies or tissues of asymptomatic mummies were excised. Peduncles were split longitudinally, and pieces approximately $2 \times 5 \times 5 \mathrm{~mm}$ in size were excised. Asymptomatic buds, emerging leaves, and flowers were cut into pieces (approximately $2 \times 5 \times 5 \mathrm{~mm}$ ) and added to $1.7-\mathrm{ml}$ microcentrifuge tubes containing $500 \mu \mathrm{l}$ of sterile deionized water. Tubes were vortexed for $10 \mathrm{~min}$ to aid in the suspension of any bacteria present. Suspensions were plated onto yeast extract-dextrose-calcium carbonate agar (YDC) (Schaad 1988) or Tween medium with $0.3 \mathrm{~g} / \mathrm{liter}$ of boric acid (McGuire et al. 1986), both amended with $100 \mathrm{mg} / \mathrm{liter}$ of cycloheximide, $33 \mathrm{mg} / \mathrm{liter}$ of cephalexin, $3.4 \mathrm{mg} / \mathrm{liter}$ of 5-fluorouracil, and $0.34 \mathrm{mg} /$ liter of tobramycin after autoclaving (YDCM and TWM, respectively). Plates were evaluated for colonies of $X$. arboricola pv. pruni after 3 to 5 days for YDCM and after 5 to 7 days for TWM at $25^{\circ} \mathrm{C}$. Candidate colonies were subcultured onto YDC and verified as $X$. arboricola pv. pruni using morphological characteristics, and a subset of isolates was subjected to PCR using species-specific primers Y17CoF and Y17CoR (Pagani 2004). An isolate of X. arboricola pv. juglandis was used to confirm primer specificity.

Koch's postulates and inoculation of almond tissues with $X$. arboricola pv. pruni in the field. Inoculations were conducted in 2016 and 2017 on approximately 10- to 11-year-old Fritz almond trees in San Joaquin County, California, on flowers at full bloom (FB; 16 February 2016 and 22 February 2017) and on immature fruit (16 April 2016 and 15 April 2017) near the end of hull expansion (Kester et al. 1996). X. arboricola pv. pruni strains Xap942 and Xap 1789 obtained from naturally infected symptomatic Nonpareil and Fritz fruit in Stanislaus and San Joaquin counties in 2013 and 2015 , respectively, were cultured from long-term storage at $-80^{\circ} \mathrm{C}$ in $20 \%$ glycerol on YDC medium for $24 \mathrm{~h}$ at $25^{\circ} \mathrm{C}$. Following subculturing and additional growth for 24 to $48 \mathrm{~h}$, bacterial suspensions were made using single strains or a mixture of the two strains in approximately equal proportions in sterile deionized water and adjusted to $1 \times 10^{8}$ (80\% transmission at $600 \mathrm{~nm}$ wavelength) bacterial cells per $1 \mathrm{ml}$. Suspensions were used for inoculations at selected phenological stages as indicated in Tables 2 and 3. For each replicate, a single branch 30 - to 70 -cm long with 12 to 100 flowers or 3 to 40 fruits was selected. Treatments were applied to runoff using a handheld spray bottle. Control treatments were sprayed with water. Branches were covered with white plastic bags for 18 to $20 \mathrm{~h}$. The bags were misted with water inside to provide a high-humidity microenvironment and keep inoculated plant tissues wet. For each treatment, 8 to 12 replications were done using 13 trees. Evaluations were conducted 4 to 8 weeks after inoculation. For this, the number of fruit with at least one sunken, corky lesion characteristic of bacterial spot was determined as well as the total number of fruit per replicate. Disease incidence on leaves was evaluated based on the number of leaves with at least one lesion on terminal $30-\mathrm{cm}$ ends of each replicate branch with approximately 200 leaves. Bacterial isolations were conducted from representative samples of symptomatic tissues as described above to verify the presence of the pathogen. 
Bactericides. Copper hydroxide (Kocide 3000; DuPont, Wilmington, DE and ChampION ${ }^{++}$Nufarm Americas, Inc., Alsip, IL) or a mixture of copper hydroxide and mancozeb (Manzate 45DF or Max; United Phosphorus, Inc., King of Prussia, PA) were used for dormant and in-season applications at rates indicated in Tables 4, 5,6 , and 7. For in-season timings with multiple copper applications, copper rates were reduced in some trials with sequential applications to mitigate phytotoxic effects (Blaauw et al. 2019).

Dormant and in-season bactericide applications. Trials were conducted in a commercial 15- to 20-year-old Fritz almond orchard on cultivar Nemaguard peach rootstock in San Joaquin County, California, with low-angle sprinkler irrigation that wetted the lower canopy (approximately $1.2 \mathrm{~m}$ from the soil surface). Dormant and in-season bactericide treatments were evaluated in 2014 to 2015, 2015 to 2016, and 2016 to 2017 studies using a split-plot design with dormant treatments as the main plots and in-season applications as the subplots. There were four single-tree replications for each treatment combination. Dormant applications with copper or copper-mancozeb were done in December (e.g., 18 December 2014, 4 December 2015, and 14 December 2016), and delayed dormant treatments were done at bud swell in January (e.g., 27 January 2015, 28 January 2016, and 25 January 2017).

In 2015 studies, dormant and delayed dormant applications were replicated in separate rows within the same orchard, and in-season applications were conducted for each. In the split plot with dormant treatments, in-season timings evaluated included one-application (11 March), two-application (4 April and 21 April), and fourapplication (25 February, 6 March, 17 March, and 6 April) spray programs with copper-mancozeb. In the split plot with delayed dormant treatments, efficacy of copper and copper-mancozeb was compared in a four-application program (25 February, 6 March, 17 March, and 6 April).

In 2016 and 2017, dormant and delayed dormant applications were applied within the same row, and in-season bactericide application timings were done as a split plot using a copper-mancozeb mixture at FB (16 February 2016 and 22 February 2017), petal fall (PF; 7 March 2016 and 15 March 2017), or both FB and PF. All applications were made using an air-blast backpack sprayer (Model SR420; Stihl Inc., Virginia Beach, VA) at 935 liters/ha. Trials were evaluated on 1 July 2015, 15 June 2016, and 6 June 2017. Disease incidence on fruit was based on the number of symptomatic fruit per

Table 2. Inoculation of flowers and immature fruit of cultivar Fritz almond with Xanthomonas arboricola pv. pruni

\begin{tabular}{|c|c|c|c|c|c|c|}
\hline \multirow{3}{*}{$\begin{array}{l}\text { Year and } \\
\text { treatment }^{\mathrm{w}}\end{array}$} & \multicolumn{6}{|c|}{$\begin{array}{l}\text { Disease incidence (\%) on fruit }{ }^{\mathrm{x}} \text { resulting from } \\
\text { inoculations of }\end{array}$} \\
\hline & \multicolumn{3}{|c|}{ Flowers (full bloom) ${ }^{y}$} & \multicolumn{3}{|c|}{ Immature fruit } \\
\hline & Range & Mean & $\overline{\mathbf{L S D}^{\mathbf{z}}}$ & Range & Mean & $\overline{\text { LSD }}$ \\
\hline \multicolumn{7}{|l|}{2016} \\
\hline Control & $0.0-5.3$ & 1.5 & $\mathrm{Ab}$ & $0.0-14.3$ & 2.4 & $\mathrm{Ab}$ \\
\hline $\begin{array}{l}\text { X. arboricola } \\
\text { pv. pruni }\end{array}$ & $0.0-66.7$ & 31.8 & $\mathrm{~B}$ a & $50.0-90.9$ & 77.7 & A a \\
\hline \multicolumn{7}{|l|}{2017} \\
\hline Control & $0.0-71.4$ & 21.2 & $\mathrm{Ab}$ & $0.0-30.4$ & 21.8 & $\mathrm{Ab}$ \\
\hline $\begin{array}{l}\text { X. arboricola } \\
\text { pv. pruni }\end{array}$ & $50.0-100.0$ & 74.9 & $\mathrm{~A} \mathrm{a}$ & $50.0-100.0$ & 71.4 & A a \\
\hline
\end{tabular}

${ }^{\mathrm{w}}$ Controls were sprayed with distilled water. For inoculations, a suspension $\left(1 \times 10^{8} \mathrm{CFU} / \mathrm{ml}\right)$ of an approximately equal mixture of $X$. arboricola $\mathrm{pv}$. pruni strains Xap 942 and Xap 1789 was used. In 2016, the two strains were used separately for flower inoculations, and data were combined.

${ }^{x}$ Diseased fruit had at least one lesion. Incidence was based on the total number of fruit per branch.

y Inoculations were done on 16 February 2016 and 22 February 2017 for flower and on 14 April 2016 and 15 April 2017 for immature fruit.

z Mean incidence values were compared using analysis of variance and least significant difference (LSD) mean separation procedures. Values followed by the same lowercase letter within a column or values followed by the same uppercase letter within a row for each tissue evaluation and year are not significantly different for different inoculation timings.
100 fruits evaluated per tree. Copper phytotoxicity of leaves was evaluated for all treatments in 2015 and 2016 and for the FB + $\mathrm{PF}$ in-season program as well as for the untreated control in 2017. For this, the terminal $30-\mathrm{cm}$ ends of four branches per tree were evaluated using a rating scale as follows: $0=$ healthy; $1=$ trace to $<5 \%$ spotted leaves; $2=5$ to $50 \%$ leaves with noticeable spotting; $3=>50 \%$ spotted leaves; and $4=$ severe spotting, tattered appearance, and leaf drop. Fruit symptoms were verified to be caused by $X$. arboricola pv. pruni by bacterial isolation from a subsample $(n=$ 10 to 12) of fruit and confirmed using PCR methods as described above. Absence of $X$. arboricola pv. pruni or of fungal infections was confirmed by isolation from leaf spots attributed to copper phytotoxicity. Following surface disinfestation as described above, small (4- to $20-\mathrm{mm}^{2}$ ) leaf pieces from the margin of lesions were suspended in sterile deionized water as above and vortexed. The suspension was plated onto YDC for bacterial isolations, or leaf tissue was placed onto potato dextrose agar amended with $130 \mathrm{mg} / \mathrm{liter}$ of ampicillin and $20 \mathrm{mg} / \mathrm{liter}$ of rifampicin for fungal isolations.

Environmental monitoring. For each winter-spring season when field studies were conducted, data for average daily temperatures and precipitation were obtained for Stations 70 (Manteca, CA; $11 \mathrm{~km}$ from trial site) and 249 (Ripon, CA: $10 \mathrm{~km}$ from trial site) from the California Irrigation Management Information System (CIMIS; https://cimis.water.ca.gov/WSNReportCriteria.aspx), and they were summarized graphically.

Statistical analysis. Isolation data were summarized by mean and range of percentage recovery of the pathogen among sampling years for each tissue type and location within a tree in relation to a symptomatic mummified fruit.

Inoculation data for 2016 and 2017 were analyzed separately. Fruit and leaf incidence were arcsine transformed prior to analysis. When the two $X$. arboricola pv. pruni strains were used separately, a generalized linear model (GLM) analysis and Levene's test for homogeneity of variance were conducted. Data were combined prior to further analysis when homogeneity of variance was upheld. GLM was used for overall model analysis following a factorial design with phenological stage, treatment, and stage $\times$ treatment interaction as factors. When the overall models were found to be significant, one-way classification of data was used for comparing treatments and phenological stages for each year following GLM and Fisher's

Table 3. Inoculation of emerging and mature leaves of cultivar Fritz almond with Xanthomonas arboricola pv. pruni

\begin{tabular}{|c|c|c|c|c|c|c|}
\hline \multirow[b]{3}{*}{ Year and treatment ${ }^{w}$} & \multicolumn{6}{|c|}{$\begin{array}{c}\text { Disease incidence (\%) on leaves }{ }^{\mathrm{x}} \text { resulting from } \\
\text { inoculations of }\end{array}$} \\
\hline & \multicolumn{3}{|c|}{ Emerging leaves $^{\mathbf{y}}$} & \multicolumn{3}{|c|}{ Mature leaves } \\
\hline & Range & Mean & $\mathbf{L S D}^{\mathbf{z}}$ & Range & Mean & LSD \\
\hline \multicolumn{7}{|l|}{2016} \\
\hline Control & $0.0-1.0$ & 0.1 & $\mathrm{Ab}$ & $0.0-1.5$ & 0.4 & $\mathrm{~A} \mathrm{~b}$ \\
\hline $\begin{array}{l}X \text {. arboricola } \\
\text { pv. pruni }\end{array}$ & $0.0-26.5$ & 5.3 & A a & $0.5-11.5$ & 5.4 & A a \\
\hline \multicolumn{7}{|l|}{2017} \\
\hline Control & $0.0-3.0$ & 0.9 & $\mathrm{Ab}$ & $0.0-2.5$ & 0.8 & $\mathrm{Ab}$ \\
\hline $\begin{array}{l}\text { X. arboricola } \\
\text { pv. pruni }\end{array}$ & $1.5-16.5$ & 7.6 & A a & $3.5-10.5$ & 6.6 & A a \\
\hline
\end{tabular}

${ }^{\mathrm{w}}$ Controls were sprayed with distilled water. For inoculations, a suspension $\left(1 \times 10^{8} \mathrm{CFU} / \mathrm{ml}\right)$ of an approximately equal mixture of $X$. arboricola pv. pruni strains Xap942 and Xap 1789 was used. In 2016, the two strains were used separately for emerging leaf inoculations, and data were combined.

x Diseased leaves had at least one lesion. Incidence was based on the total number of leaves on the terminal $30-\mathrm{cm}$ ends of each branch.

y Inoculations were done on 16 February 2016 and 22 February 2017 for emerging leaves and on 14 April 2016 and 15 April 2017 for mature leaves.

z Mean incidence values were compared using analysis of variance and least significant difference (LSD) mean separation procedures. Values followed by the same lowercase letter within a column or values followed by the same uppercase letter within a row for each tissue evaluation and year are not significantly different for different inoculation timings. 
least significant difference (LSD) pairwise mean separation procedures.

The four bactericide trials were analyzed separately. Disease incidence data were arcsine transformed prior to analysis, and phytotoxicity severity ratings were not transformed. Analysis of variance (ANOVA) or GLM procedures were conducted for the overall models according to a split-plot design as described above. When the overall models were found to be significant, one-way classification of data was used for comparing in-season treatments separately for each dormant treatment and dormant treatments separately for each in-season program following ANOVA or GLM and Fisher's LSD mean separation procedures. Fisher's LSD mean separation procedures were also conducted for main plot and subplot factor means using combined data.
All statistical procedures were done using SAS (version 9.4; SAS Institute, Inc., Cary, NC). A significance value of $\alpha=0.1$ was used for GLM or ANOVA overall and one-way classification models, and a significance value of $\alpha=0.05$ was used for multiple comparison procedures.

\section{Results}

Identification of overwintering structures. X. arboricola pv. pruni was recovered from $40.0 \%$ of the symptomatic mummies collected and from $51.4 \%$ of their associated peduncles (Table 1). The pathogen was isolated from $19.4 \%$ of asymptomatic flowers and $3.4 \%$ of emerging leaves when these tissues were collected adjacent to a symptomatic mummy in the tree canopy. X. arboricola pv. pruni was not isolated from asymptomatic mummies, dormant bud

Table 4. Effect of dormant treatments and timing of in-season bactericide treatments on the incidence of bacterial spot on fruit and copper phytotoxicity on leaves of cultivar Fritz almond in San Joaquin County in a study from 2014 to 2015

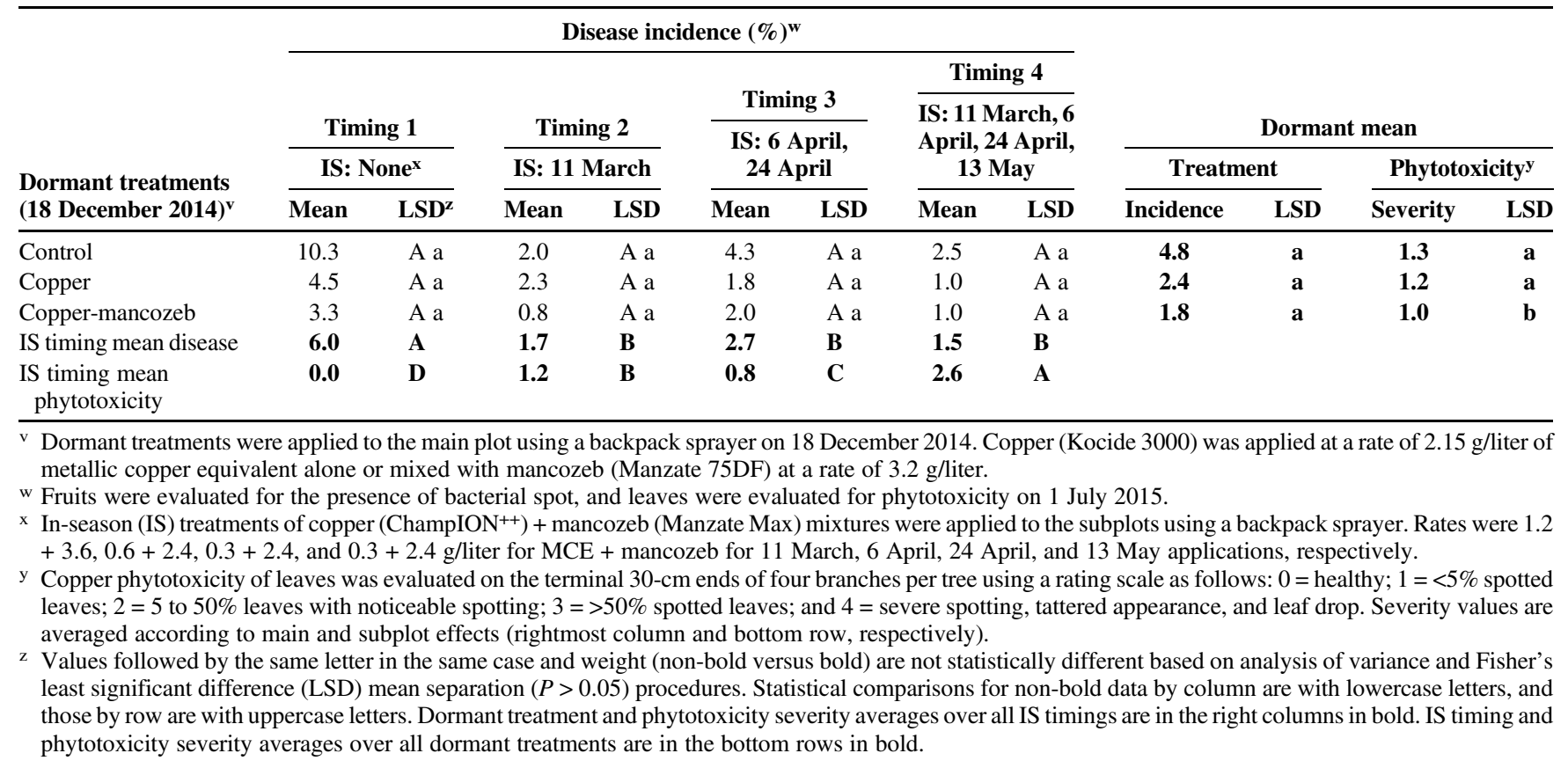

Table 5. Effect of delayed dormant and in-season bactericide treatments on the incidence of bacterial spot on fruit and copper phytotoxicity on leaves of cultivar Fritz almond in San Joaquin County in 2015

\begin{tabular}{|c|c|c|c|c|c|c|c|c|c|c|}
\hline \multirow{4}{*}{$\begin{array}{l}\text { Delayed dormant } \\
\text { treatments }(27 \\
\text { January 2015) }\end{array}$} & \multicolumn{6}{|c|}{ Disease incidence $(\%)^{\mathrm{w}}$} & \multirow{2}{*}{\multicolumn{4}{|c|}{ Delayed dormant mean }} \\
\hline & \multirow{2}{*}{\multicolumn{2}{|c|}{ IS: None ${ }^{\mathrm{x}}$}} & \multirow{2}{*}{\multicolumn{2}{|c|}{ IS: Copper }} & \multirow{2}{*}{\multicolumn{2}{|c|}{$\begin{array}{c}\text { IS: Copper + } \\
\text { manzate }\end{array}$}} & & & & \\
\hline & & & & & & & \multicolumn{2}{|c|}{ Treatment } & \multicolumn{2}{|c|}{ Phytotoxicity ${ }^{y}$} \\
\hline & Mean & $\mathbf{L S D}^{\mathbf{z}}$ & Mean & LSD & Mean & LSD & Incidence & LSD & Severity & LSD \\
\hline Control & 4.5 & A a & 1.3 & $\mathrm{~B}$ a & 0.8 & $\mathrm{~B} \mathrm{a}$ & 2.2 & $\mathbf{a}$ & 0.6 & $\mathbf{a}$ \\
\hline Copper & 2.0 & A a & 1.0 & $\mathrm{~A}$ a & 0.5 & A a & 1.2 & $\mathbf{a}$ & 0.7 & $\mathbf{a}$ \\
\hline Copper + mancozeb & 2.3 & A a & 0.8 & $\mathrm{AB}$ a & 0.0 & $\mathrm{~B} \mathrm{a}$ & 1.0 & $\mathbf{a}$ & 0.8 & $\mathbf{a}$ \\
\hline $\begin{array}{l}\text { IS treatment mean } \\
\text { disease }\end{array}$ & 2.9 & $\mathbf{A}$ & 1.0 & B & 0.4 & B & & & & \\
\hline $\begin{array}{l}\text { IS treatment mean } \\
\text { phytotoxicity }\end{array}$ & 0.0 & B & 0.9 & $\mathbf{A}$ & 1.1 & $\mathbf{A}$ & & & & \\
\hline
\end{tabular}

\footnotetext{
$\mathrm{v}$ Delayed dormant treatments were applied to the main plot on 27 January 2015. Copper (Kocide 3000) was applied at a rate of $2.15 \mathrm{~g} /$ liter of metallic copper equivalent alone or mixed with mancozeb (Manzate 45DF) at a rate of $3.2 \mathrm{~g} /$ liter.

${ }^{w}$ Fruits were evaluated for the presence of bacterial spot, and leaves were evaluated for phytotoxicity on 1 July 2015.

${ }^{x}$ In-season (IS) treatments of copper (ChampION ${ }^{++}$) or copper-mancozeb (Manzate Max) mixtures were applied to the subplots. Copper rates were 1.2, 0.6, 0.3, and $0.3 \mathrm{~g} /$ liter of metallic copper equivalent and mancozeb rates were 3.6, 2.4, 2.4, and $2.4 \mathrm{mg} /$ liter for 11 March, 6 April, 24 April, and 13 May applications, respectively.

y Severity of copper phytotoxicity on leaves was evaluated on the terminal $30-\mathrm{cm}$ ends of four branches per tree using a rating scale as follows: $0=$ healthy; $1=$ $<5 \%$ spotted leaves; $2=5$ to $50 \%$ leaves with noticeable spotting; $3=>50 \%$ spotted leaves; and $4=$ severe spotting, tattered appearance, and leaf drop. Severity values were averaged based on main and subplot effects (rightmost column and bottom row, respectively).

z Values followed by the same letter in the same case and weight (non-bold versus bold) are not statistically different based on analysis of variance and Fisher's least significant difference (LSD) mean separation $(P>0.05)$ procedures. Statistical comparisons for non-bold data by column are with lowercase letters, and those by row are with uppercase letters. Dormant treatment and phytotoxicity severity averages over all IS timings are in the right columns in bold. IS timing and phytotoxicity severity averages over all delayed dormant treatments are in the bottom rows in bold.
} 
samples, or flowers that were collected either $>2 \mathrm{~m}$ from a symptomatic mummy or from a tree where mummified fruits were not present.

On YDCM, X. arboricola pv. pruni candidate colonies were yellow, convex, mucoid, and shiny (EPPO 2005). On TWM, they were light yellow, convex, mucoid, and shiny, and they were surrounded by a white halo of minute crystals in the agar as a result of Tween lipolysis by the bacterium (McGuire et al. 1986). On both media, yellow coloration darkened over time. PCR amplification with $X$. arboricola pv. pruni-specific primers $\mathrm{Y} 17 \mathrm{CoF}$ and $\mathrm{Y} 17 \mathrm{CoR}$ resulted in a single band of the expected 943-bp size.

Mummified fruit, especially those collected from the orchard floor, resulted in high levels of bacterial contamination even when using semiselective media. For these samples, X. arboricola pv. pruni was more easily recovered from symptomatic mummies on
TWM medium compared with YDCM (data not shown). On YDCM, different bacteria with yellow pigmentation were isolated from symptomatic and asymptomatic mummified fruit but with various shades of yellow (e.g., neon yellow or orange-yellow), consistency, and morphological characteristics distinct from $X$. arboricola pv. pruni. These bacterial contaminants did not result in positive PCR identification using $X$. arboricola pv. pruni-specific primers.

Effect of in-season inoculations on disease incidence. In 2016 inoculations of flowers, disease incidence on fruit was not significantly $(P=0.3278)$ different for strains Xap942 (35.0\%) and Xap1789 (28.8\%). In inoculations of emerging leaves, disease incidence was also not significantly $(P=0.2732)$ different for the two strains (6.5 and $4.3 \%$, respectively), but both were significantly different from the negative control $(P<0.05)$. Because homogeneity of

Table 6. Effect of dormant and in-season bactericide treatment timings on the incidence of bacterial spot on fruit and copper phytotoxicity on leaves of cultivar Fritz almond in San Joaquin County in a study from 2015 to 2016

\begin{tabular}{|c|c|c|c|c|c|c|c|c|c|c|c|c|}
\hline \multirow{5}{*}{$\begin{array}{l}\text { Dormant treatment } \\
\text { timing }^{v}\end{array}$} & \multicolumn{8}{|c|}{ Disease incidence $(\%)^{w}$} & & & & \\
\hline & \multirow{3}{*}{\multicolumn{2}{|c|}{$\begin{array}{c}\text { Timing } 1 \\
\text { IS: } \text { None }^{\mathrm{x}}\end{array}$}} & \multirow{3}{*}{\multicolumn{2}{|c|}{$\begin{array}{c}\text { Timing } 2 \\
\begin{array}{c}\text { IS: } 16 \text { February } \\
\text { (FB) }\end{array}\end{array}$}} & \multirow{3}{*}{\multicolumn{2}{|c|}{$\begin{array}{c}\text { Timing } 3 \\
\begin{array}{c}\text { IS: } 7 \text { March } \\
\text { (PF) }\end{array}\end{array}$}} & \multirow{3}{*}{\multicolumn{2}{|c|}{$\begin{array}{c}\text { Timing } 4 \\
\text { IS: } 16 \\
\text { February, } \\
7 \text { March } \\
\text { (FB, PF) }\end{array}$}} & \multirow{2}{*}{\multicolumn{4}{|c|}{ Dormant timing mean }} \\
\hline & & & & & & & & & & & & \\
\hline & & & & & & & & & \multicolumn{2}{|c|}{ Treatment } & \multicolumn{2}{|c|}{ Phytotoxicity } \\
\hline & Mean & $\overline{\text { LSD }^{\mathbf{z}}}$ & Mean & $\overline{\text { LSD }}$ & Mean & $\overline{\text { LSD }}$ & Mean & $\overline{\text { LSD }}$ & Incidence & $\overline{\text { LSD }}$ & Severity & $\overline{\text { LSD }}$ \\
\hline$\overline{\text { Control }}$ & 9.0 & $\mathrm{~A} \mathrm{a}$ & 7.5 & $\mathrm{AB} \mathrm{a}$ & 5.0 & $\mathrm{AB} \mathrm{a}$ & 1.0 & $\mathrm{~B}$ a & 5.4 & $\mathbf{a}$ & 1.5 & $\mathbf{a}$ \\
\hline $\begin{array}{l}\text { Dormant (4 December } \\
\text { 2015) }\end{array}$ & 4.3 & $\mathrm{Ab}$ & 0.5 & $\mathrm{~B} \mathrm{~b}$ & 0.3 & $\mathrm{~B}$ a & 2.7 & $\mathrm{AB}$ a & 1.9 & ab & 1.5 & $\mathbf{a}$ \\
\hline $\begin{array}{l}\text { Delayed dormant } \\
\text { (28 January 2016) }\end{array}$ & 0.8 & $\mathrm{Ab}$ & 0.8 & $\mathrm{Ab}$ & 0.5 & A a & 1.5 & A a & 0.9 & b & 1.6 & $\mathbf{a}$ \\
\hline $\begin{array}{l}\text { IS treatment mean } \\
\text { disease }\end{array}$ & 4.3 & $\mathbf{A}$ & 2.9 & $\mathbf{A B}$ & 1.9 & B & 1.6 & B & & & & \\
\hline $\begin{array}{l}\text { IS timing mean } \\
\text { phytotoxicity }\end{array}$ & 0.0 & $\mathbf{C}$ & 0.9 & B & 2.6 & $\mathbf{A}$ & 2.9 & $\mathbf{A}$ & & & & \\
\hline 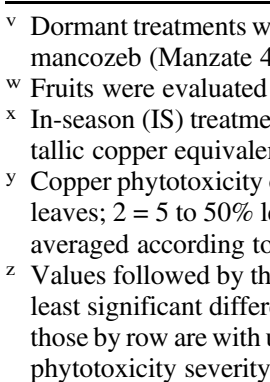 & $\begin{array}{l}\text { applied } \\
\text { F) at a } \\
\text { r the pre } \\
\text { of copp } \\
\text { mixed w } \\
\text { leaves w } \\
\text { ves with } \\
\text { lain and } \\
\text { ame lett }\end{array}$ & $\begin{array}{l}\text { the main } \\
\text { of } 3.2 \\
\text { ace of ba } \\
\text { (Champ } \\
\text { mancoz } \\
\text { evaluate } \\
\text { ticeable } \\
\text { bplot eff } \\
\text { n the sar } \\
\text { ean sep. }\end{array}$ & $\begin{array}{l}\text { lot. Copp } \\
\text { iter. } \\
\text { erial spot } \\
\mathrm{N}^{++} \text {)-ma } \\
\text { at a rate } \\
\text { on the ter } \\
\text { otting; } 3 \\
\text { ts (rightm } \\
\text { case and } \\
\text { tion }(P>\end{array}$ & $\begin{array}{l}\text { (Champ } \\
\text { dd leaves } \\
\text { ozeb (M } \\
3.6 \text { g/li } \\
\text { nal } 30-\mathrm{cr} \\
50 \% \text { sp } \\
\text { t colum } \\
\text { eight (no }\end{array}$ & $\begin{array}{l}\mathrm{N}^{++} \text {) was } \\
\text { vere evall } \\
\text { zate } 45 \mathrm{DI} \\
\text { at full bl } \\
\text { ends of fo } \\
\text { ted leaves } \\
\text { and botto } \\
\text {-bold ver }\end{array}$ & $\begin{array}{l}\text { pplied a } \\
\text { ted for } \mathrm{p} \\
\text { were ap } \\
\text { m (FB) } \\
\text { branch } \\
\text { and } 4= \\
\text { row, re } \\
\text { bold) }\end{array}$ & $\begin{array}{l}\text { rate of } 2 \text {. } \\
\text { totoxicit } \\
\text { led to the } \\
\text { hd/or pet } \\
\text { per tree u } \\
\text { ere spott } \\
\text { ctively). } \\
\text { not stati } \\
\text { arisons f }\end{array}$ & $\begin{array}{l}\mathrm{g} / \text { liter o } \\
\text { on } 15 \mathrm{Ju} \\
\text { bplots. } \\
\text { fall (PF } \\
\text { hg a rati } \\
\mathrm{g} \text {, tatter } \\
\text { cally dif } \\
\text { non-bol }\end{array}$ & $\begin{array}{l}\text { netallic coppe } \\
2016 . \\
\text { pper was app } \\
\text { scale as follo } \\
\text { appearance, a } \\
\text { ent based on } \\
\text { lata by colum } \\
\text { are in the rigl }\end{array}$ & $\begin{array}{l}\text { equivale } \\
\text { d at a } \mathrm{r} \\
0=\text { he } \\
\text { leaf } \mathrm{dr} \\
\text { alysis o } \\
\text { are with }\end{array}$ & $\begin{array}{l}\text { alone or mi } \\
\text { of } 1.2 \mathrm{~g} / \mathrm{lite} \\
\text { hy; } 1=<5 \% \\
\text { Severity va } \\
\text { ariance and } \\
\text { wercase let } \\
\text { bold. IS tin }\end{array}$ & $\begin{array}{l}\text { d with } \\
\text { of me- } \\
\text { potted } \\
\text { les are } \\
\text { isher's } \\
\text { rs, and } \\
\text { ng and }\end{array}$ \\
\hline
\end{tabular}

Table 7. Effect of dormant and in-season bactericide treatment timings on the incidence of bacterial spot on cultivar Fritz almond fruit in San Joaquin County in a study from 2016 to 2017

\begin{tabular}{|c|c|c|c|c|c|c|c|c|c|c|}
\hline \multirow[b]{5}{*}{ Dormant treatment timingw } & \multicolumn{8}{|c|}{ Disease incidence $(\%)^{x}$} & & \\
\hline & \multirow{3}{*}{\multicolumn{2}{|c|}{$\begin{array}{c}\text { Timing } 1 \\
\text { IS: None }^{\mathrm{y}}\end{array}$}} & \multirow{3}{*}{\multicolumn{2}{|c|}{$\begin{array}{c}\text { Timing } 2 \\
\text { IS: } 22 \text { February } \\
\text { (FB) } \\
\end{array}$}} & \multirow{3}{*}{\multicolumn{2}{|c|}{$\begin{array}{c}\text { Timing } 3 \\
\begin{array}{c}15 \text { March } \\
(\text { PF })\end{array}\end{array}$}} & \multirow{3}{*}{\multicolumn{2}{|c|}{$\begin{array}{c}\text { Timing } 4 \\
\text { IS: } 22 \\
\text { February, 15 } \\
\text { March }(\mathrm{FB}, \text { PF) } \\
\end{array}$}} & \multirow{3}{*}{\multicolumn{2}{|c|}{$\begin{array}{c}\text { Dormant timing } \\
\text { mean }\end{array}$}} \\
\hline & & & & & & & & & & \\
\hline & & & & & & & & & & \\
\hline & Mean & $\mathbf{L S D}^{\mathbf{z}}$ & Mean & LSD & Mean & LSD & Mean & LSD & Incidence & LSD \\
\hline Control & 41.3 & A a & 16.3 & $\mathrm{~B}$ a & 0.8 & $\mathrm{C} \mathrm{a}$ & 3.0 & $\mathrm{Ca}$ & 13.6 & a \\
\hline Dormant (14 December 2016) & 10 & $\mathrm{Ab}$ & 4.3 & A a & 1.3 & A a & 3.3 & A a & 4.7 & b \\
\hline Delayed dormant (25 January 2017) & 8.8 & $\mathrm{Ab}$ & 9.0 & A a & 2.5 & A a & 1.8 & A a & 5.5 & b \\
\hline IS treatment mean disease & 18.1 & A & 10.4 & $\mathbf{A}$ & 1.5 & B & 2.7 & B & & \\
\hline
\end{tabular}

${ }^{w}$ Dormant treatments were applied to the main plot. Copper $\left(\mathrm{ChampION}^{++}\right)$was applied at a rate of $2.15 \mathrm{~g} /$ liter of metallic copper equivalent alone or mixed with mancozeb (Manzate 45DF) at a rate of $3.2 \mathrm{~g} /$ liter.

$\mathrm{x}$ Fruits were evaluated for the presence of bacterial spot on 6 June 2017.

y In-season (IS) treatments of copper (ChampION ${ }^{++}$)-mancozeb (Manzate 45DF) mixtures were applied to the subplots using a backpack sprayer. Rates were 1.2 $+2.4 \mathrm{~g} /$ liter for MCE + mancozeb for single applications at full bloom (FB) and petal fall (PF; timings 2 and 3), whereas for FB + PF (timing 4), the copper rate was reduced to $0.6 \mathrm{~g} /$ liter of metallic copper equivalent for the PF application.

z Values followed by the same letter in the same case and weight (non-bold versus bold) are not statistically different based on analysis of variance and Fisher's least significant difference (LSD) mean separation $(P>0.05)$ procedures. Statistical comparisons for non-bold data by column are with lowercase letters, and those by row are with uppercase letters. Dormant treatment averages over all IS timings are in the right columns in bold. IS timing averages over all dormant treatments are in the bottom row in bold. 
variance was upheld $(P=0.1452$ and $P=0.7951$ for fruit and leaf evaluations, respectively), data were combined.

Inoculations resulted in disease development, with fruit and leaf symptoms similar to those described previously on almond and observed for natural infections in California (Table 2). X. arboricola pv. pruni was consistently reisolated from inoculated fruit and leaves, and PCR amplification with $X$. arboricola pv. pruni-specific primers $\mathrm{Y} 17 \mathrm{CoF}$ and $\mathrm{Y} 17 \mathrm{CoR}$ resulted in a single band of the expected 943-bp size, fulfilling Koch's postulates.

The overall models for 2016 and 2017 inoculation studies were significant for disease incidence of fruit $(P<0.0001)$, with treatment (i.e., inoculation; $P<0.0001)$, phenological stage $(P=0.0024)$, and interaction $(P=0.0035)$ factors significantly contributing to the model in 2016; however, only the treatment $(P<0.0001)$ factor contributed significantly to the model in 2017 . Thus, phenological stage and interaction factors were not significant $(P=0.7716$ and $P=$ 0.4841 , respectively). Following one-way data classification, inoculations resulted in significantly higher disease levels compared with the water control for all four year $\times$ stage fruit disease evaluation groups $(P<0.0001$ to $P<0.0006)$.

In 2016, inoculations of flowers resulted in a significantly $(P<$ $0.0001)$ lower disease incidence compared with inoculation conducted at the immature fruit stage, whereas in 2017, inoculations at both stages were statistically similar $(P=0.7461)$ (Tables 2 and 3$)$. Some water controls showed low levels of fruit disease incidence in 2016 (means of 1.5 and $2.4 \%$ for flower and immature fruit inoculations, respectively) and moderate levels of disease in 2017 (means of 21.2 and $21.8 \%$ for flower and immature fruit inoculations, respectively). These were statistically similar among inoculation stages for each year $(P=0.8897$ and $P=0.5293$ for 2016 and 2017, respectively).
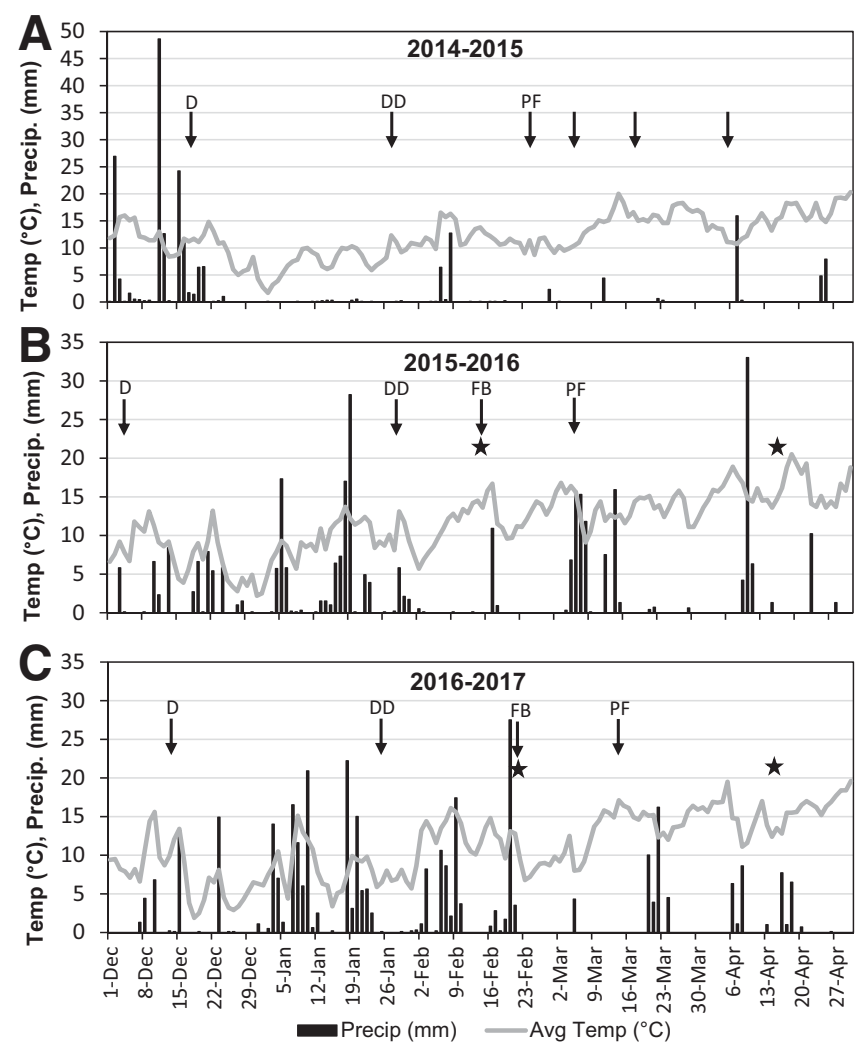

Fig. 1. Environmental conditions near the field trial location in Ripon, California, during the winter and spring of the A, 2014 to 2015, B, 2015 to 2016, and C, 2016 to 2017 seasons. Black arrows indicate bactericide application timings for dormant (D), delayed dormant $(\mathrm{DD})$, full bloom (FB), petal fall (PF), and post-PF in-season applications for trials conducted each year. Stars in B and C indicate bacterial inoculation dates for flowers/emerging leaves in February and for immature fruit/ mature leaves in April.
For incidence of spotted leaves, the overall models for 2016 and 2017 were significant $(P<0.0001)$, with treatment $(P<0.0001)$ significantly contributing to the model but not phenological stage or the interaction $(P=0.7696$ and $P=0.7169$ for 2016 and $P=0.7556$ and $P=0.9068$ for 2017 , respectively). No significant differences were observed in diseased leaf count for similar treatments inoculated at emerging or mature leaf stages for either year $(P=0.4112$ to $P=$ 0.9589) (Table 3). All inoculations with $X$. arboricola pv. pruni resulted in significantly $(P<0.0001$ to $P<0.0091)$ higher disease compared with the respective water controls.

Effect of dormant and in-season bactericide applications on disease incidence. Fruit lesions with amber-colored gumming were the predominant disease symptom observed in each year. $X$. arboricola pv. pruni was consistently isolated from these lesions, verifying the presence of bacterial spot. None of the leaf spot isolations resulted in the recovery of the bacterial pathogen or fungi, indicating that copper phytotoxicity was the cause.

Following a relatively wet December and dry spring season in 2014 to 2015 (total rainfall from 1 December to 30 April was $207.5 \mathrm{~mm}$, with $148.1 \mathrm{~mm}$ in December) (Fig. 1A), disease was first observed in late May (during the fruit pit-hardening stage), and the incidence was overall low at evaluation time. Averages of 10.3 and $4.5 \%$ of fruits on control trees were diseased in trials 1 and 2, respectively (Tables 4 and 5). Still, the overall models for disease incidence were significant $(P=0.0009$ and $P=0.0787$ for trials 1 and 2 , respectively), and because the interaction between dormant and in-season treatments was not significant $(P=0.5928$ and $P=0.8674$, respectively), data were combined and interpreted across in-season and dormant treatments for each trial for evaluation of overall factor effects (Tables 4 and 5). Neither dormant nor delayed dormant applications significantly reduced the disease compared with the untreated control in trials $1(P=0.4214)$ and $2(P=0.1236)$. In-season applications with copper-mancozeb (Table 4$)$ or with copper and coppermancozeb (Table 5) significantly $(P=0.0029$ and $P=0.0007$, respectively) reduced the disease compared with the untreated control.

In the 2015 to 2016 and 2016 to 2017 trials, following relatively wet winter and spring seasons with total rainfall from 1 December 2015 to 30 April 2016 of $311.0 \mathrm{~mm}$ (Fig. 1B) and from 1 December 2016 to 30 April 2017 of $338.3 \mathrm{~mm}$ (Fig. 1C), the disease was first observed in late April. Disease incidences on untreated trees were 9.0 and $41.3 \%$ in the two trials, respectively. Overall model $(P<$ 0.0001 and $P<0.0027$ for the two studies, respectively), dormant $(P=0.0700$ and $P=0.0045$, respectively), and in-season $(P=$ 0.0072 and $P<0.0001$, respectively) factors as well as the interaction between dormant and in-season bactericide timings in both trials were significant $(P=0.0020$ and $P=0.0124$, respectively).

Following one-way classification of data according to in-season bactericide timing (Tables 6 and 7), dormant applications significantly $(P=0.0088$ for 2015 to 2016 and $P=0.0231$ for 2016 to 2017) reduced disease incidence when no in-season timings were applied and when copper/mancozeb was applied at FB in 2015 to 2016 (timing 2; $P=0.0299)$ but not in 2016 to $2017(P=0.1842)$. For these, dormant timings were statistically similar $(P>0.05)$. Dormant treatments were not significant when followed by a single bactericide treatment at PF (timing 3; $P=0.1155$ for 2015 to 2016 and $P=$ 0.4526 for 2016 to 2017 ) or by two treatments at FB and PF (timing 4; $P=0.7362$ for 2015 to 2016 and $P=0.4873$ for 2016 to 2017 ).

Following one-way classification of data according to dormant timing (Tables 6 and 7), in-season bactericide applications significantly reduced the disease when no dormant treatment was applied in 2015 to $2016(P=0.0697)$ and 2016 to $2017(P=0.0001)$ and following the dormant bactericide application in 2015 to $2016(P=$ 0.0388). When no dormant treatment was applied in 2015 to 2016, timing $4(\mathrm{FB}+\mathrm{PF})$ significantly $(P<0.05)$ reduced the disease compared with the control (timing 1 ), but it was not statistically different $(P>0.05)$ from in-season timings 2 and 3. In 2016 to 2017, all three in-season timings significantly $(P<0.05)$ reduced the disease compared with the control without a dormant treatment, with timings 3 (PF only) and 4 (FB and PF) resulting in a statistically lower disease incidence compared with timing 2 (FB only). Following dormant 
application of copper/mancozeb, in-season timings 2 (FB) and 3 (PF) resulted in statistically $(P<0.05)$ lower disease compared with the control (timing 1) in 2015 to 2016 , but they were not statistically significant $(P=0.3695)$ in 2016 to 2017 . In-season treatments following delayed dormant timing of copper/mancozeb application were not significant in the 2015 to 2016 and 2016 to 2017 studies $(P=$ 0.8638 and $P=0.1623$, respectively).

Effect of dormant and in-season bactericide applications and timings on copper phytotoxicity on leaves. No phytotoxicity was observed on trees receiving no in-season bactericide applications. The overall models for phytotoxicity were significant in all trials $(P<0.0001, P=0.0016, P<0.0001$, and $P=0.0418$ for 2014 to 2015 trial 1, 2014 to 2015 trial 2, 2015 to 2016, and 2016 to 2017 , respectively), and because there was no interaction between dormant and in-season treatments $(P=0.3313, P=0.8599, P=0.1909$, and $P$ $=0.4402$, respectively), data were combined and interpreted across levels by trial for evaluation of overall factor effects (Tables 4, 5, and 6). Dormant treatments were only found to significantly contribute to the model in trial 1 in 2014 to $2015(P=0.0066)$, where a dormant application of copper-mancozeb had significantly lower phytotoxicity averaged across in-season applications compared with the control and copper alone. In-season bactericide application programs had a significant effect in all trials $(P<0.0001, P<0.0001$, $P<0.0001$, and $P=0.0003$ for 2014 to 2015 trial 1,2014 to 2015 trial 2, 2015 to 2016 , and 2016 to 2017 , respectively), and all inseason bactericide application timings and treatments resulted in significantly $(P>0.05)$ higher phytotoxicity compared with the respective controls. In trial 1 in 2014 to 2015, phytotoxicity was highest in the four-application program (timing 4, rating 2.6) followed by the single-application (timing 2, rating 1.2) and two-application (timing 3, rating 0.8) spray programs (Table 4). In trial 2 in 2014 to 2015 , no differences $(P>0.05)$ were observed between copper and copper-mancozeb mixtures in a four-application program (Table 5). In 2015 to 2016, timings 3 (PF, rating 2.6) and 4 (FB + $\mathrm{PF}$, rating 2.9) had the highest phytotoxicity and were significantly higher than for timing 2 (FB, rating 0.9) (Table 6). In 2016 to 2017, phytotoxicity was low, and the two-spray FB + PF program resulted in a mean rating of 0.8 .

\section{Discussion}

Bacterial spot is reported herein as a new disease of almond in California. Koch's postulates were fulfilled, and the pathogen $X$. arboricola pv. pruni was identified using specific PCR primers. The disease has been previously reported from almond and stone fruits in other parts of the world (Palacio-Bielsa et al. 2017; Ritchie $1995)$, and the pathogen was first detected and confirmed on almond in California in 2013 (Holtz et al. 2013). Symptomatic mummified fruit and their peduncles were identified as the primary overwintering sites for $X$. arboricola pv. pruni in California orchards. Mummified fruit are also implicated as overwintering sites of bacterial spot of almond in Spain and Australia (Palacio-Bielsa et al. 2017; Roselló et al. 2012). Removal of mummified fruit during dormancy, which is also important for the management of navel orangeworm (Amyelois transitella) (Zalom et al. 1984), is, therefore, a cultural practice that can reduce primary inoculum of $X$. arboricola pv. pruni the following spring. To our knowledge, this is also the first report of the presence of $X$. arboricola pv. pruni in peduncles associated with infected mummified fruit. This is important because the peduncle of an almond fruit remains attached to the tree and is part of the woody spur. Therefore, even when mummified fruit are removed, the infected peduncle remains a potential source of primary inoculum in the orchard canopy. In other growing regions of almond, twig lesions/cankers and dormant buds are also reported as overwintering sites of $X$. arboricola pv. pruni (Palacio-Bielsa et al. 2017; Roselló et al. 2012), and these in addition to leaf scar infections are the primary overwintering locations in other hosts such as peach (Battilani et al. 1999; Ritchie et al. 2008; Zaccardelli et al. 1995). We did not observe such twig lesions, and the bacterium was not recovered from buds. It remains possible that these overwintering sites exist in California orchards, but they probably have a minor role. Recovery of the bacterium from asymptomatic flowers and emerging leaves was dependent on their proximity to symptomatic mummified fruit, suggesting that the bacterium may have spread from the infected mummy, likely by rain splash or dripping dew.

Recovery of $X$. arboricola pv. pruni from symptomatic mummified fruit was low for some collections, possibly because of high levels of contamination even when semiselective media were used or because of low bacterial levels in the tissues. Population sizes of $X$. arboricola pv. pruni in the various tissues were not quantified, but even small amounts of viable bacterial cells may exponentially increase to high concentrations in overwintering structures during favorable temperature and wetness conditions. Additionally, because multiple yellow-pigmented bacteria other than $X$. arboricola pv. pruni were isolated from mummified fruit, proper bacterial species identification with species-specific primers is important for pathogen diagnosis.

Inoculations of flowers and fruit as well as immature and mature leaves of Fritz almond resulted in disease development, indicating a long period of host susceptibility to infection during the spring season. Disease incidence was low on inoculated leaves and low to high on fruit following flower and fruit inoculations. These disease levels are similar to those observed naturally on leaves and fruit in California. Disease development on fruit was lower after flower than after immature fruit inoculations in 2016; however, in 2017, there was no difference between the two inoculations. Wetness conditions based on total hourly (data not shown) and daily rainfall as well as relative humidity values (total hours $\geq 98 \%$; data not shown) from nearby CIMIS stations were similar during the incubation period in both years. Optimum environmental conditions for bacterial spot development on almond are not known, although the disease is more common in areas with temperate, humid climates (Palacio-Bielsa et al. 2017). Thus, regional environmental conditions recorded at nearby CIMIS stations cannot explain the difference in disease development between the years. The high disease levels observed after flower inoculations in 2017 , however, may also be owing to the presence of high natural inoculum levels in the orchard that led to fruit infections. High natural inoculum levels were evident by the relatively high disease incidence on branches with flowers or fruit (21.2 and $21.8 \%$, respectively) that served as noninoculated controls and by high disease levels in our management plots $(41.3 \%$ in the untreated control) (Table 7) in 2017. Alternatively, in flower inoculations, $X$. arboricola pv. pruni possibly did not infect immediately but instead, remained epiphytic for a period of time (Shepard and Zehr 1994). Thus, disease observed after flower inoculation may have resulted from fruit infection by epiphytic populations. Microscopic visualization of the infection process may lead to a better understanding of the specific infection timing and mechanism in almond, although our studies demonstrate that a wound is not necessary for infection. Previous studies on other hosts indicate that the bacterium can enter tissues via natural openings, such as stomata and lenticels, or through wounds, such as leaf scars, and the pathogen has the potential to move systemically (du Plessis 1986; Roselló et al. 2012).

Successful inoculations of immature fruit demonstrate the potential for high disease development under natural conditions when springtime rains occur. Infections later in the season may have less impact on yield and kernel quality because hardening of kernels and endocarps (i.e., pit hardening) occurs in late spring (May to June) (Kester et al. 1996), and there may not be enough time for the pathogen to grow into these tissues to cause losses after this time period. Still, the disease has been observed to reach epidemic levels in orchards where high-angle impact sprinkler irrigation in May, June, and July wets the lower tree canopy, creating a conducive microclimate (J. E. Adaskaveg, unpublished data). Therefore, use of microsprinkler or drip irrigation that does not wet tree canopies should be beneficial to reduce bacterial spot.

Development of bacterial spot on Prunus spp. depends greatly on climatic conditions, with warm temperatures and wet conditions favoring disease (Battilani et al. 1999; Palacio-Bielsa et al. 2017; Stefani 2010). In this study, dry spring conditions in 2015 correlated with relatively low disease in both trials. In 2016, disease was 
observed at similar levels as in 2015, despite the occurrence of more rainfall. This may be because low disease levels in 2015 resulted in a small overwintering population of the bacterium and correspondingly, low primary inoculum populations in the spring of 2016.

Dormant applications significantly reduced the disease in years with more rainfall (i.e., 2015 to 2016 and 2016 to 2017 trials), even without in-season applications, but they did not in a dry year (i.e., 2014 to 2015 trials). Copper and copper-mancozeb treatments showed high efficacy against bacterial spot in our trials under California conditions in dormant and delayed dormant applications. In high-rainfall spring seasons (2015 to 2016 and 2016 to 2017 trials), dormant as well as in-season FB plus PF or PF applications alone significantly reduced the disease compared with the untreated control in the overall main effects model of the split plot. In low-rainfall seasons (2014 to 2015), dormant treatments were not effective, but inseason applications of copper-mancozeb at PF or later significantly reduced the disease from the untreated control. This differs from reports from other geographical regions and from other hosts, where chemical treatments are considered only moderately effective under low to moderate disease pressure (Palacio-Bielsa et al. 2017; Ritchie 1999; Ritchie et al. 2008). Still, in our study, an interaction was observed between dormant and in-season timings in the high-rainfall seasons, indicating that the efficacy of specific combinations of these applications was probably dependent on microclimatic conditions and phenological stages during application of the bactericides.

Determination of optimal spray timings is important for the most efficient and cost-effective disease management compared with a calendar-based spray schedule. Optimal timing may also reduce chemical load in the environment by reducing the number of sprays. Lastly, optimal timings have been shown to prevent resistance development in a pathogen population (van den Berg et al. 2013). Because copper and mancozeb are currently registered in the United States for management of diseases of almond, preserving their efficacy for bacterial spot is relevant. Furthermore, our efficacy data will support the addition of bacterial spot to labels of these compounds. Evaluation of population-level sensitivities of $X$. arboricola pv. pruni to these compounds and monitoring of any changes in sensitivity are warranted, especially because copper resistance is present in Michigan populations of X. arboricola pv. pruni (McGrath et al. 2009) as well as in California populations of $X$. arboricola pv. juglandis (causal agent of walnut blight) (Nguyen et al. 2016).

Copper use is limited by the risk of phytotoxicity, especially if multiple applications have to be done. This is demonstrated in some of our studies, and differences in phytotoxicity levels are likely owing to annual differences in microclimates. For example, rain can reduce copper residues on plant surfaces, minimizing buildup. Phytotoxicity was generally higher with repeated in-season applications when foliage was present, which was observed as well in peach (Blaauw et al. 2019; Ritchie et al. 2008). With phytotoxicity as a limiting factor for copper usage and label restrictions in the use of mancozeb that prohibit its use later than 5 weeks after PF, evaluation of other new bactericide treatments with different modes of action and that do not cause phytotoxicity is warranted for the management of bacterial spot of almond in California.

\section{Acknowledgments}

We recognize John Edstrom, Dr. Brent Holtz, Roger Duncan, and David Doll (University of California Cooperative Extension; farm advisors in Colusa, San Joaquin, Stanislaus, and Merced County, respectively) who brought this disease to the attention of the industry. We also recognize Dr. Themis Michailides for coincidental isolations of the pathogen and thank him for insightful discussions on pathogen survival. We thank G. Gemelga and D. Murillo for assisting in bacterial isolations and disease evaluations, the grower in San Joaquin County who allowed trials to be performed in his orchard, and registrants for donation of bactericide products.

\section{Literature Cited}

Akhatar, M. A., Rahber-Bhatti, M. H., and Haque, M. I. 1995. Bacterial spot of almond caused by Xanthomonas campestris pv. pruni in Pakistan. Pak. J. Phytopathol. 7:88-89.

Battilani, P., Rossi, V., and Saccardi, A. 1999. Development of Xanthomonas arboricola pv. pruni epidemics on peaches. J. Plant Pathol. 81:161-171.
Blaauw, B., Brannen, P., Lockwood, D., and Ritchie, D. 2019. Southeastern peach, nectarine and plum pest management and cultural guide. Georgia Extension Bulletin No. 1171. University of Georgia Cooperative Extension Service, College of Agricultural and Environmental Sciences, Athens, GA.

Buchner, R. P., Gilles, C., Olson, W. H., Adaskaveg, J. E., Lindow, S. E., and Koutsoukis, R. 2010. Spray timing and materials for walnut blight (Xanthomonas campestris pv. juglandis, Xanthomonas arboricola pv. juglandis) control in northern California USA. Acta Hortic. 861:457-464.

du Plessis, H. J. 1986. Systemic migration and establishment of Xanthomonas campestris pv. pruni in plum leaves and twigs. J. Phytopathol. 116:221-227.

EPPO. 1997. Data sheet on Xanthomonas arboricola pv. pruni. European and Mediterranean Plant Protection Organization. Pages 1096-1011 in: Quarantine Pests for Europe, 2nd Ed. D. McNamara, I. Smith, P. Scott, and M. Holderness, eds. CAB International, Wallingford, United Kingdom.

EPPO. 2005. Diagnostic protocol for Xanthomonas arboricola pv. pruni. PM 7/64 OEPP/EPPO Bulletin 36:135-144. European and Mediterranean Plant Protection Organization, Paris, France.

EPPO. 2015. Xanthomonas arboricola pv. pruni. European and Mediterranean Plant Protection Organization. In: Distribution Maps of Plant Diseases No. 340, 6th Ed. CAB International, Wallingford, United Kingdom.

Fones, H., and Preston, G. M. 2013. The impact of transition metals on bacterial plant disease. FEMS Microbiol. Rev. 37:495-519.

FRAC. 2019. FRAC Code List 2019: Fungicides sorted by mode of action (including FRAC code numbering). Fungicide Resistance Action Committee. https://web.archive.org/web/20200114075759/http://www.frac.info:80/docs/ default-source/publications/frac-code-list/frac-code-list-2019.pdf

Grass, G., Rensing, C., and Solioz, M. 2011. Metallic copper as an antimicrobial surface. Appl. Environ. Microbiol. 77:1541-1547.

Gullino, M. L., Tinivella, F., Garibaldi, A., Kemmitt, G. M., Bacci, L., and Sheppard, B. 2010. Mancozeb: Past, present, and future. Plant Dis. 94: 1076-1087.

Holtz, B., Doll, D., Duncan, R., Edstrom, J., Michailides, T., and Adaskaveg, J. 2013. Bacterial spot on almond found in the San Joaquin Valley. Almond Digest. University of California Cooperative Extension, San Joaquin County, California. http://ipm.ucanr.edu/PDF/MISC/168605.pdf

Jindal, K. K., Sharma, R. C., and Gupta, V. K. 1990. Xanthomonas campestris pv. pruni on almond leaves and fruits in India. Indian Phytopathol. 43:436-438.

Kester, D. E., Martin, G. C., and Labavitch, J. M. 1996. Growth and development. Pages 90-97 in: Almond Production Manual, Publication 3364. W. C. Micke ed. University of California, Division of Agriculture and Natural Resources, Oakland, CA.

Lamichhane, J. R. 2014. Xanthomonas arboricola diseases of stone fruit, almond, and walnut trees: Progress toward understanding and management. Plant Dis. 98:1600-1610

McGrath, M. J., Lesniak, K. E., Cogal, A. G., Ma, Z., and Sundin, G. W. 2009 Oxytetracycline- and copper-resistance in Xanthomonas arboricola pv. pruni isolates from Michigan orchards. (Abstract). Phytopathology 99:S82.

McGuire, R. G., Jones, J. B., and Sasser, M. 1986. Tween media for semiselective isolation of Xanthomonas campestris pv. vesicatoria from soil and plant material. Plant Dis. 70:887-891.

Nguyen, K., Förster, H., Wade, L., and Adaskaveg, J. 2016. Kasugamycin mixtures with copper, mancozeb, or a thiadiazole improve bactericidal inhibition and efficacy of treatments against walnut blight. (Abstract) Phytopathology 106:S4.62.

Pagani, M. C. 2004. An ABC transporter protein and molecular diagnoses of Xanthomonas arboricola pv. pruni causing bacterial spot of stone fruits. $\mathrm{PhD}$ thesis, North Carolina State University, Raleigh, NC.

Palacio-Bielsa, A., Cambra, M., Martínez, C., Olmos, A., Pallás, V., López, M. M., Adaskaveg, J. E., Förster, H., Cambra, M. A., Duval, H., and Esmenjaud, D. 2017. Almond diseases. Pages 321-374 in: Almonds: Botany, Production, and Uses. R. Socias i Company and T. M. Gradziel, eds. CAB International, Wallingford, United Kingdom.

Palacio-Bielsa, A., Roselló, M., Cambra, M. A., and López, M. M. 2010. First report on almond in Europe of bacterial spot disease of stone fruits caused by Xanthomonas arboricola pv. pruni. Plant Dis. 94:786.

Ritchie, D. F. 1995. Bacterial spot. Pages 50-52 in: Compendium of Stone Fruit Diseases. J. M. Ogawa, E. I. Zehr, G. W. Bird, D. F. Ritchie, K. Uriu, and J. K. Uyemoto, eds. American Phytopathological Society, St. Paul, MN.

Ritchie, D. F. 1999. Sprays for control of bacterial spot of peach cultivars having different levels of disease susceptibility, 1998. Fungicide Nematic. Tests 54: 63-64.

Ritchie, D. F., Barba, M., and Pagani, M. C. 2008. Diseases caused by prokaryotes-bacteria and phytoplasmas. Pages 407-434 in: The Peach: Botany, Production and Uses. D. Layne and D. Bassi, eds. CAB International, Wallingford, United Kingdom.

Roselló, M., Santiago, R., Palacio-Bielsa, A., García-Figures, F., Montón, C., Cambra, M. A., and López, M. M. 2012. Current status of bacterial spot of stone fruits and almond caused by Xanthomonas arboricola pv. pruni in Spain. J. Plant Pathol. 94:S15-S21.

Schaad, N. W. 1988. Pages 81-82 in: Laboratory Guide for the Identification of Plant Pathogenic Bacteria. The American Phytopathological Society, St. Paul, $\mathrm{MN}$ 
Shepard, D. P., and Zehr, E. I. 1994. Epiphytic persistence of Xanthomonas campestris pv. pruni on peach and plum. Plant Dis. 78:627-629.

Smith, E. F. 1903. Observations on a hitherto unreported bacterial disease, the cause of which enters the plant through ordinary stomata. Science 17:456-457.

Stefani, E. 2010. Economic significance and control of bacterial spot/canker of stone fruits caused by Xanthomonas arboricola pv pruni. J. Plant Pathol. 92:S99-S103.

van den Berg, F., van den Bosch, F., and Paveley, N. D. 2013. Optimal fungicide application timings for disease control are also an effective anti-resistance strategy: A case study for Zymoseptoria tritici (Mycosphaerella graminicola) on wheat. Phytopathology 103:1209-1219.
Vauterin, L., Hoste, B., Kersters, K., and Swings, J. 1995. Reclassification of Xanthomonas. Int. J. Syst. Bacteriol. 45:472-489.

Young, J. M. 1977. Xanthomonas pruni in almond in New Zealand. N. Z. J. Agric. Res. 20:105-107.

Zaccardelli, M., Consiglio, M. F., and Mazzucchi, U. 1995. Detection of Xanthomonas campestris pv. pruni in symptomless peach trees in winter. Phytopathol. Mediterr. 34:199-203

Zalom, F. G., Weakley, C., Hendricks, L. C., Bentley, W. J., Barnett, W. W., and Connell, J. H. 1984. Cultural management of the navel orange worm by winter sanitation. Calif. Agric. 38:28. 